\title{
USE OF HONEYBEES AS BIO-INDICATORS OF ENVIRONMENTAL POLLUTION IN THE KURDISTAN PROVINCE OF IRAN
}

\author{
Amin Sadeghi ${ }^{1}$, Ali-Akbar Mozafari ${ }^{2}$, \\ Reza Bahmani ${ }^{3}$, Kamran Shokri ${ }^{4}$ \\ ${ }^{1}$ Department of Plant Protection, Faculty of Agriculture, \\ University of Kurdistan, Sanandaj, Iran \\ ${ }^{2}$ Department of Horticulture, Faculty of Agriculture, \\ University of Kurdistan, Sanandaj, Iran \\ ${ }^{3}$ Young Researchers' Club, Sanandaj Branch, \\ Islamic Azad University, Sanandaj, Iran \\ ${ }^{4}$ Department of Agronomy, Faculty of Agriculture, \\ University of Kurdistan, Sanandaj, Iran \\ e-mail: a.sadeghi@uok.ac.ir
}

Received 25 July; accepted 14 November 2012

$$
\text { S u m m a r y }
$$

The aim of this study was to determine the levels of these elements: $\mathrm{Hg}, \mathrm{Ba}, \mathrm{Ca}, \mathrm{Fe}, \mathrm{Mn}, \mathrm{Li}, \mathrm{As}$, $\mathrm{Na}$ and $\mathrm{K}$ in the bodies of bees. Honeybee samples were randomly collected from apiaries located in four counties of the province of Kurdistan. The four counties were: Marivan, Bijar, Kamyaran and Ghorveh. The data obtained from this study showed that $\mathrm{K}$ had the highest concentration, followed by $\mathrm{Na}, \mathrm{Ca}, \mathrm{Hg}, \mathrm{Ba}, \mathrm{Fe}, \mathrm{Mn}, \mathrm{Li}$ and As. From among all the sites, there were no significant differences recorded between the concentrations of the different metals. The results did show that three minerals groups were able to be differentiated: elements that were very abundant, elements in a medium concentration, and trace elements. The first group consisted of $\mathrm{K}$ and $\mathrm{Na}$, with a range from 41.857 to 47.871, and 12.653 to $16.183 \mathrm{ppm}$, respectively. The second mineral group was composed of $\mathrm{Ca}$, $\mathrm{Hg}, \mathrm{Ba}$, and $\mathrm{Fe}$, where $\mathrm{Ca}$ was the most abundant element (with a range of 9.077 to $10.058 \mathrm{ppm}$ ), followed by $\mathrm{Hg}(1.12-4.786 \mathrm{ppm}), \mathrm{Ba}(2.881-3.481 \mathrm{ppm})$, and $\mathrm{Fe}(1.050-1.727 \mathrm{ppm})$. The third mineral group was composed of $\mathrm{Mn}, \mathrm{Li}$ and As. They ranged from 0.262 to -0.399 , and from 0.043 to 0.101 , and from 0.017 to $0.068 \mathrm{ppm}$, respectively.

Keywords: honeybee, bioindicator, environmental pollution, elements, Kurdistan province.

\section{INTRODUCTION}

The interest in bioindicator-based techniques for the detection and evaluation of environmental contaminants has increased during the past two decades. Several animal species have been suggested to be suitable for the monitoring of environmental pollution. Mussels (Dreissena polymorpha) (Binelli et al., 2001; Szefe et al., 2002); herrings (Clupea harengus), and partridges (Alectoris rufa) (Herrera et al., 2000) or even mammals such as cattle (LópezAlonso et al., 2002) and fox (Corsolini et al., 2000) have been suggested for the monitoring of environmental pollution. Since 1970, honeybees (Apis mellifera) have increasingly been used to monitor heavy metal environmental pollutants as reported in some studies (Porrini et al., 2002; Bromenshenk et al., 1985). The reason for the use of honeybees is that they reveal the chemical impairment of the environment mainly in two ways: first, through high mortality, and second, because honey bees intercept particles suspended in the air or in the blossoms and then the particles are retained in the honeybee's hairs or the particles accumulate within the honeybee's body. These substances can 
then be detected using appropriate analysis methods (Kevan, 1999; Porrini et al., 2000).

It is important to note, that metals do not cause honey bee mortality but can accumulate in their body. Thus, the contamination in the form of heavy metals building up in the honeybee's body may reflect the contamination of plants, soil, air, and water in a certain area. According to many investigations (Porrini et al., 2003; Perugini et al., 2011; Crane, 1984) bees are good indicators of pollution in a given area, and the range of their visitation is $3 \mathrm{~km}^{2}$ (Devillers et al., 2002).

The aim of this pilot study was to evaluate the effectiveness of honeybees as biological indicators of the presence of mercury $(\mathrm{Hg})$, barium $(\mathrm{Ba})$, calcium $(\mathrm{Ca})$, iron $(\mathrm{Fe})$, manganese $(\mathrm{Mn})$, lithium $(\mathrm{Li})$, arsenic (As), sodium (Na), and potassium $(\mathrm{K})$ in the environment, by comparing data obtained from different counties being sampled.

\section{MATERIALS AND METHODS}

The research materials were samples of honeybees obtained from bee colonies maintained in stationary apiaries located in four counties of the province of Kurdistan: Marivan, Bijar, Kamyaran and Ghorveh. The province of Kurdistan is in western Iran (Fig. 1). Honey bee bodies were collected in September 2011. From the apiaries located in the four counties, Marivan, Bijar, Kamyaran, and Ghorveh 7, 4, 7, and 4 samples were collected, respectively.
Samples were put in chemically-cleaned polyethylene bags from which drones, sticks, and pebbles were removed. The collected bees were killed in a laboratory by freezing at $-18{ }^{\circ} \mathrm{C}$, and then, dried at $45^{\circ} \mathrm{C}$, homogenized by grinding, and carefully mixed. A test portion for mineralization of a mass of about $1,000 \mathrm{mg}$ (with an accuracy of $0.10 \mathrm{mg}$ ) was prepared from each sample. Test portions were then diluted with a $20 \mathrm{ml}$ solution of concentrated, spectrally pure nitric acid (Riedel-de Haen 30702 Company), and then mineralized using the microwave technique under increased pressure in a microprocessor microwave furnace, MARS 5 Company CEM (14-stands).

The contents of $\mathrm{Hg}, \mathrm{Ba}, \mathrm{Ca}, \mathrm{Fe}, \mathrm{Mn}, \mathrm{Li}$, $\mathrm{As}, \mathrm{Na}$, and $\mathrm{K}$ were determined directly using atomic absorption spectroscopy (GF 3000 model AAS, Graphite Furnace GF 3000, Auto Sampler GBC PAL 3000, GBC Scientific Equipment Pty Ltd, Australia). Calibration curves were prepared by diluting stock solutions.

Analysis of variance (ANOVA) was performed based on unbalanced completely randomized for the measurement of all elements in the bodies of bees. Significant differences between the means of measurements were determined using Duncan's multiple range test (DMRT) at the $\mathrm{P}=0.05$ level. All statistical analyses were performed using a computer and the SAS software package (SAS Institute, Cary, NC, USA).

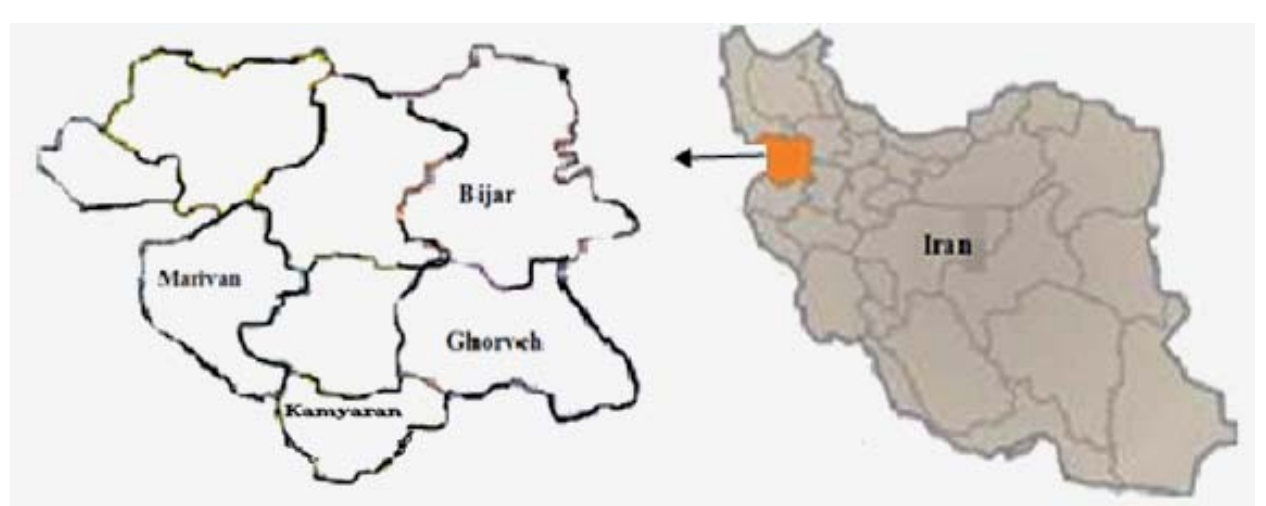

Fig. 1. Locations of the studied counties (Marivan, Kamyaran, Bijar, and Ghorveh) on the map of the Kurdistan province. 


\section{RESULTS}

The average values of element concentrations in the honeybee samples are given with their standard deviations in Tables 1, 2, and 3. The samples are from individual sites in the counties of Marivan, Bijar, Kamyaran, and Ghorveh.

According to these data, $\mathrm{K}$ has the highest concentration followed by $\mathrm{Na}, \mathrm{Ca}, \mathrm{Hg}, \mathrm{Ba}$, $\mathrm{Fe}, \mathrm{Mn}, \mathrm{Li}$, and As. Regional comparisons were also examined in this study. Significant differences were not recorded between the concentrations of elements in any of the areas (Tab. 1, 2, and 3). Three groups of minerals were distinguished: elements that were very abundant, elements with medium concentrations, and trace elements. The first group consisted of $\mathrm{K}$ and $\mathrm{Na}$ which ranged from 41.857 to 47.871 , and 12.653 to $16.183 \mathrm{ppm}$, respectively (Tab. 1). The second mineral group was composed of $\mathrm{Ca}, \mathrm{Hg}, \mathrm{Ba}$, and $\mathrm{Fe}$. From this group, $\mathrm{Ca}$ was the most abundant with a range of 9.077 to $10.058 \mathrm{ppm}$ followed by $\mathrm{Hg}$ (1.125-4.786 ppm), Ba (2.881$3.481 \mathrm{ppm})$, and $\mathrm{Fe}(1.050-1.727 \mathrm{ppm})$ (Tab. 2). The third mineral group was composed of $\mathrm{Mn}, \mathrm{Li}$, and $\mathrm{As}$, and they ranged from 0.262 to $0.399,0.043$ to 0.101 and 0.017 to $0.068 \mathrm{ppm}$ (Tab. 3), respectively.

Honeybee samples collected from the apiaries of Marivan had the highest $\mathrm{K}$ (47.871 ppm) content followed by Bijar (47.780 ppm), Kamyaran (46.066 ppm), and Ghorveh (41.857 ppm).

In the case of $\mathrm{Na}$, the highest content was in honeybees from Bijar (16.183 ppm), followed by Ghorveh (15.845 ppm), Marivan (15.250 ppm), and Kamyaran (12.653 ppm). The higher (10.058 ppm) and lower $(9.077 \mathrm{ppm}) \mathrm{Ca}$ concentrations were found in the samples of Ghorveh and Kamyaran, respectively. Table 1 shows that the highest concentration of $\mathrm{Hg}$ was in the samples of Kamyaran (4.786 ppm), whereas the lowest content was found in Ghorveh (1.125 ppm) samples.

Table 1 .

Range, mean, and standard deviation values of $\mathrm{K}$, and $\mathrm{Na}$ (ppm) in honeybees of four counties of the Kurdistan province

\begin{tabular}{|c|c|c|c|}
\hline \multicolumn{2}{|c|}{ Region } & $\mathrm{K}$ & $\mathrm{Na}$ \\
\hline $\begin{array}{l}\text { Marivan } \\
(\mathrm{n}=7)\end{array}$ & $\begin{array}{l}\text { Mean } \pm S D \\
\text { Range }\end{array}$ & $\begin{array}{c}47.871 \pm 5.681 \mathrm{a} \\
(38.63-56.63)\end{array}$ & $\begin{array}{c}15.250 \pm 7.547 a \\
(0.00-18.3)\end{array}$ \\
\hline $\begin{array}{l}\text { Bijar } \\
(n=4)\end{array}$ & $\begin{array}{l}\text { Mean } \pm S D \\
\text { Range }\end{array}$ & $\begin{array}{c}47.780 \pm 7.552 a \\
(37.88-56.2)\end{array}$ & $\begin{array}{c}16.183 \pm 2.801 \mathrm{a} \\
(12.55-18.8)\end{array}$ \\
\hline $\begin{array}{c}\text { Kamyaran } \\
(n=7)\end{array}$ & $\begin{array}{l}\text { Mean } \pm S D \\
\text { Range }\end{array}$ & $\begin{array}{c}46.066 \pm 11.955 a \\
(32.02-65.5)\end{array}$ & $\begin{array}{c}12.653 \pm 8.743 a \\
(0.00-19.5)\end{array}$ \\
\hline $\begin{array}{c}\text { Ghorveh } \\
(n=4)\end{array}$ & $\begin{array}{l}\text { Mean } \pm S D \\
\text { Range }\end{array}$ & $\begin{array}{c}41.857 \pm 9.835 \mathrm{a} \\
(29.48-52.75)\end{array}$ & $\begin{array}{c}15.845 \pm 1.186 a \\
(14.72-17.01)\end{array}$ \\
\hline
\end{tabular}

Mean \pm standard deviation and range.

Table 2 .

Range, mean, and standard deviation values of $\mathrm{Ca}, \mathrm{Hg}, \mathrm{Ba}$, and $\mathrm{Fe}(\mathrm{ppm})$ in honeybees of four counties of the Kurdistan province

\begin{tabular}{|c|c|c|c|c|c|}
\hline \multicolumn{2}{|c|}{ Region } & $\mathrm{Ca}$ & $\mathrm{Hg}$ & $\mathrm{Ba}$ & $\mathrm{Fe}$ \\
\hline $\begin{array}{l}\text { Marivan } \\
(\mathrm{n}=7)\end{array}$ & $\begin{array}{l}\text { Mean } \pm S D \\
\text { Range }\end{array}$ & $\begin{array}{c}9.863 \pm 1.539 a \\
(7.624-12.28)\end{array}$ & $\begin{array}{c}3.357 \pm 4.506 a \\
(0.00-9.5)\end{array}$ & $\begin{array}{l}3.117 \pm 0.578 a \\
(2.075-3.925)\end{array}$ & $\begin{array}{c}1.050 \pm 0.430 \mathrm{a} \\
(0.352-1.602)\end{array}$ \\
\hline $\begin{array}{l}\text { Bijar } \\
(n=4)\end{array}$ & $\begin{array}{l}\text { MeantSD } \\
\text { Range }\end{array}$ & $\begin{array}{c}9.743 \pm 1.693 a \\
(7.203-10.59)\end{array}$ & $\begin{array}{c}4.750 \pm 6.837 \mathrm{a} \\
(0.00-14.5)\end{array}$ & $\begin{array}{c}3.481 \pm 0.306 a \\
(3.05-3.7)\end{array}$ & $\begin{array}{c}1.577 \pm 0.579 a \\
(0.832-2.083)\end{array}$ \\
\hline $\begin{array}{c}\text { Kamyaran } \\
(n=7)\end{array}$ & $\begin{array}{l}\text { Mean } \pm S D \\
\text { Range }\end{array}$ & $\begin{array}{c}9.077 \pm 1.442 \mathrm{a} \\
(6.355-10.59)\end{array}$ & $\begin{array}{c}4.786 \pm 6.836 \mathrm{a} \\
(0.00-14.5)\end{array}$ & $\begin{array}{c}2.992 \pm 0.302 \mathrm{a} \\
(2.35-3.25)\end{array}$ & $\begin{array}{c}1.438 \pm 1.526 a \\
(0.73-4.89)\end{array}$ \\
\hline $\begin{array}{l}\text { Ghorveh } \\
(n=4)\end{array}$ & $\begin{array}{l}\text { Mean } \pm S D \\
\text { Range }\end{array}$ & $\begin{array}{c}10.058 \pm 1.216 a \\
(8.474-11.44)\end{array}$ & $\begin{array}{c}1.125 \pm 2.249 a \\
(0.00-4.499)\end{array}$ & $\begin{array}{c}2.881 \pm 0.701 \mathrm{a} \\
(2.00-3.7)\end{array}$ & $\begin{array}{c}1.727 \pm 1.173 a \\
(0.56-3.339)\end{array}$ \\
\hline
\end{tabular}

Mean \pm standard deviation and range. 
Range, mean, and standard deviation values of $\mathrm{Mn}, \mathrm{Li}$, and As (ppm) in honeybees of four counties of the Kurdistan province

\begin{tabular}{|c|c|c|c|c|}
\hline \multicolumn{2}{|c|}{ Region } & $\mathrm{Mn}$ & $\mathrm{Li}$ & As \\
\hline $\begin{array}{l}\text { Marivan } \\
(\mathrm{n}=7)\end{array}$ & $\begin{array}{l}\text { Mean } \pm S D \\
\text { Range }\end{array}$ & $\begin{array}{c}0.367 \pm 0.104 a b \\
(0.232-0.549)\end{array}$ & $\begin{array}{c}0.093 \pm 0.046 a \\
(0.00-0.107) \\
\end{array}$ & $\begin{array}{r}0.040 \pm 0.036 a \\
(0.000-0.093) \\
\end{array}$ \\
\hline $\begin{array}{l}\text { Bijar } \\
(n=4)\end{array}$ & $\begin{array}{l}\text { Mean } \pm S D \\
\text { Range }\end{array}$ & $\begin{array}{c}0.346 \pm 0.044 a b \\
(0.302-0.408)\end{array}$ & $\begin{array}{c}0.043 \pm 0.051 a \\
(0.007-0.013)\end{array}$ & $\begin{array}{c}0.017 \pm 0.020 \mathrm{a} \\
(0.000-0.038) \\
\end{array}$ \\
\hline $\begin{array}{l}\text { Kamyaran } \\
(n=7)\end{array}$ & $\begin{array}{l}\text { MeantSD } \\
\text { Range }\end{array}$ & $\begin{array}{c}0.262 \pm 0.089 b \\
(0.197-0.408)\end{array}$ & $\begin{array}{c}0.082 \pm 0.045 a \\
(0.014-0.142)\end{array}$ & $\begin{array}{c}0.068 \pm 0.056 a \\
(0.000-0.144)\end{array}$ \\
\hline $\begin{array}{c}\text { Ghorveh } \\
(n=4)\end{array}$ & $\begin{array}{l}\text { MeantSD } \\
\text { Range }\end{array}$ & $\begin{array}{c}0.399 \pm 0.078 a \\
(0.302-0.479)\end{array}$ & $\begin{array}{c}0.101 \pm 0.042 a \\
(0.05-0.142)\end{array}$ & $\begin{array}{c}0.034 \pm 0.047 a \\
(0.00-0.103) \\
\end{array}$ \\
\hline
\end{tabular}

Mean \pm standard deviation and range.

Mean within the same columns with different letters are statistically significant $(\mathrm{P}<0.05)$.

The highest $\mathrm{Ba}$ contents were recorded in samples of bees collected from Bijar, followed by Marivan, Kamyaran, and Ghorveh, with the mean values being 3.481, $3.117,2.992$, and $2.881 \mathrm{ppm}$, respectively. The highest mean concentration of $\mathrm{Fe}$ was $1.727 \mathrm{ppm}$ in the samples of Ghorveh and the lowest $\mathrm{Fe}$ value was found as $1.050 \mathrm{ppm}$ from the samples of Marivan (Tab. 2). The minimum and maximum Mn concentrations were observed in the bee samples of Kamyaran 0.262 ppm, and in the bee samples of Ghorveh $0.399 \mathrm{ppm}$, respectively.

In Table 3, the highest concentration of Li was measured at $0.101 \mathrm{ppm}$ in the bee samples of Ghorveh. The lowest Li content was found as $0.043 \mathrm{ppm}$ in the Bijar samples. Moreover, the As concentration determined in the bee samples of Kamyaran, Marivan, Ghorveh, and Bijar were $0.068,0.040,0.034$, and $0.017 \mathrm{ppm}$, respectively (Tab. 3 ).

\section{DISCUSSION}

There are a few publications dealing with honeybees and metal pollution (Crane, 1984, Porrini et al., 2003; Perugini et al., 2011). In the current research, the highest concentration of $\mathrm{Hg}$ was measured as $4.786 \mathrm{ppm}$ in the samples from Kamyaran. The lowest $\mathrm{Hg}$ content was found as $1.125 \mathrm{ppm}$ in the Ghorveh samples. Perugini et al.
(2011) did not demonstrate Hg presence in honeybee samples. In principle, the pollutants can be accumulated in soil and plants (Spodniewska, 2007), and are collected by bees along with nectar and pollen (Roman, 2004; Roman, 2009). Depending on the chemical properties of the substances, nectar is contaminated by pollutants to a higher or lower extent. Therefore, if nectar functions in a polluted environment, plant products used by bees may also be contaminated. As a result, a part of these pollutants will accumulate in the organism's body.

Our results showed that bee bodies are contaminated by elements in various concentrations. The range of the concentration is mainly dependent on the region of the apiary location. This observation (Tab. 1 and 2) is confirmed in the related literature by Bromenshenk et al. (1985) and Veleminsky et al. (1990) who believe that the amount of heavy metals in bee's bodies reflects their concentration in the environment where the insects live. Thus, bees and their products might be used in quality monitoring for environmental toxic metal contamination (Accorti et al., 1990; Balestra et al., 1992; Leita et al., 1996). It should be noted that there is a close correlation between the accumulation of metals in soil and plants as well as metal contents in honeybees and honeybee products (Roman, 2004). The present research demonstrated that honeybee bodies exhibited the highest level 
of metals. In accordance with the author's previous studies (unpublished data), the concentration of all metals in honey was greatly lower than the concentration of all metals in the body of the bee. Probably during the processing of raw material for honey production, bee bodies partially purify this product from contamination.

\section{CONCLUSION}

This study shows the chemical composition of major, minor, and toxic elements in the bee samples from four counties in western Iran.

The data obtained from this study do not allow any specific conclusions concerning the extent of bioaccumulation of mercury, barium, calcium, iron, manganese, lithium, arsenic, sodium, and potassium in the environment, but showed the capacity of bees to detect the metal concentrations in reserves. These insects are able to detect an early warning of changing environmental conditions and could be an attractive way to assess anthropogenic changes during long periods.

\section{REFERENCES}

Accorti M., Guardini R., Modi G., Perano-Oddo L. (1990) - Urban pollution and honey bees. Apicoltura, 6: 43-55.

Balestra V., Celli G.,Porrini C. (1992) - Bees, honey, larvae and pollen in biomonitoring of atmospheric pollution. Aerobiologia, 8: 122-126.

Binelli A., Bacchetta R., Vailati G., Galassi S., Provini A. (2001) - DDT contamination in Lake Maggiore (N. Italy) and effects on zebra mussel spawning. Chemosphere, 45:409-415.

Bromenshenk J. J., Carlson S. R., Simpson J. C., Thomas J. M. (1985) - Pollution monitoring of Puget Sound with honeybees. Science, 227: 632-634.

Corsolini S., Burrini L., Focardi S., Lovardi S. (2000) - How can we use the red fox as bioindicator of organochlorines? Arch. Environ. Contam. Toxicol., 39: 547-556.
Crane E. (1984) - Bees, honey and pollen as indicators of metals in the envirnment. Bee World, 55: 47-49.

Devillers J., Pham-Delegue M. H., (2002) - Honey Bees: Estimating the environmental impact of chemicals. Taylor and Francis, London and New York, pp. 332.

Herrera A., Ariño A., Conchello M. P., Lázaro R., Bayarri S., Yagùe C. (2000) - Red-legged partridges (Alectoris rufa) as bioindicators for persistent chlorinated chemicals in Spain. Arch. Environ. Contam. Toxicol., 38: 114-120.

Kevan G. P. (1999) - Pollinator as bioindicators of the state of the environment: Species, activity and diversity. Agric. Ecosyst. Environ., 74: 373-393.

Leita L., Muhlbachova G., Cesco S. Barbattini R., Mondini C. (1996) Investigation of the use of honey bees and honey bee products to assess heavy metals contamination. Environ. Monit. Assess., 43: 1-9.

López Alonso M., Benedito J. L., Miranda M., Castillo C., Herna'ndez J., Shore R. F. (2002) Cattle as biomonitors of soil arsenic, copper, and zinc concentrations in Galicia (NW Spain). Arch. Environ. Contam. Toxicol., 43: 103-108.

Perugini M., Manera M., Grotta L., Abete M. C., Tarasco R. (2011) - Heavy Metal $(\mathrm{Hg}, \mathrm{Cr}, \mathrm{Cd}$, and $\mathrm{Pb})$ Contamination in Urban Areas and Wildlife Reserves: Honeybees as Bioindicators. Biol. Trace. Elem. Res., 140: 170-176.

Porrini C., Celli G., Radegui P., Marini S., Maccagnani B.(2000)-Studies on the use of honeybees (Apis mellifera L.) as bioindicators of metals in the. Insect Social Life, 3: 153-159.

Porrini C., Ghini S., Girotti S., Sabatini A.G., Gattavecchia E., Celli G. (2002) - Use of honeybees as bioindicators of environmental pollution in Italy, in: Devillers J., Pham-Delègue M.H.(Eds.) Honey bees: Estimating the environmental impact of chemicals, Taylor \& Francis, London and New York, pp. 186-247. 
Porrini C., Sabatini A. G., Girotti S., Ghini S., Medrzycki P., Grillenzoni F., Bortolotti L., Gattavecchia E., Celli G. (2003) - Honeybees and bee products as monitors of the environmental contamination. Apiacata, 38: 63-70.

Roman A. (2004) - The heavy metals content in bee's nectar and mature honey. Scientific Exercise Books of Agricultural University in Wrocław, LI., 501: 297.

Roman A. (2009) - Concentration of Chosen Trace Elements of Toxic Properties in Bee Pollen Loads. Pol. J. of Environ. Stud., 18(2): 265-272.

Spodniewska A. (2007) - Lead and cadmium content in bees from apiaries of Warmia and Mazury province. Veterinary Medicine, 63: 736.
Szefe P., Frelek., Szefer K., Lee Ch.B., Kim B. S, Warzocha J. (2002) Distribution and relationships of trace metals in soft tissue, byssus and shells of Mytilus edulis trossulus from the southern Baltic. Environ Pollut., 120: 423-44.

Veleminsky M., Laznicka P., Stary P. (1990) - Honeybees (Apis mellifera L.) as environmental monitors of heavy metals in Czechoslovakia. Acta Entomol. Bohemoslov., 87: 37-44.

\title{
PSZCZOLY JAKO BIOINDYKATORY SKAŻENIA ŚRODOWISKA W PROWINCJI KURDYSTAN, IRAN
}

\author{
Sadeghi A., Mozafari A., \\ Bahmani R., Shokri K.
}

$$
\text { S t r e s z c z e n i e }
$$

Celem niniejszych badań było określenie zawartości następujących pierwiastków: $\mathrm{Hg}, \mathrm{Ba}, \mathrm{Ca}$, Fe, Mn, Li, As, Na i K w ciele pszczół. Próby pszczół zostały pobrane losowo z czterech okręów prowincji Kurdystan: Marivan, Bijar, Kamyaran i Ghorveh. Zebrane dane wykazały, że najwyższe stężenia osiagał $\mathrm{K}$, a następnie $\mathrm{Na}, \mathrm{Ca}, \mathrm{Hg}, \mathrm{Ba}, \mathrm{Fe}, \mathrm{Mn}, \mathrm{Li}$ i As. Nie stwierdzono istotnych różnic porównując stężenia metali w próbach pochodzących z różnych lokalizacji. Na podstawie wyników wyodrębniono trzy grupy pierwiastków: pierwiastki występujące obficie, pierwiastki osiagające średnie stężenia i pierwiastki występujące w ilościach śladowych. Pierwszą grupę pierwiastków tworzyły K i Na, których stężenia wynosiły odpowiednio od 41,857 do 47,871 i od 12,653 do $16,183 \mathrm{ppm}$. Drugą grupę tworzyły $\mathrm{Ca}, \mathrm{Hg}$, Ba i Fe, przy czym najwyższe stężenia osiagał $\mathrm{Ca}(9,077-$ 10,058 ppm), następnie $\mathrm{Hg}(1,12-4,786$ ppm), Ba (2,881-3,481 ppm) i Fe (1,050-1,727 pm). Trzecia grupa zawierała Mn, Li i As. Wartości ich stężeń wynosiły odpowiednio od 0,262 do 0,399, od 0,043 do 0,101 i od 0,017 do 0,068 ppm.

Słowa kluczowe: pszczoła miodna, bioindykator, skażenie środowiska, pierwiastki, prowincja Kurdystan. 